IRSTI 06.52.13

\title{
I.N. Dubina
}

Novosibirsk National Research State University (NSU), Russia, Novosibirsk

Altai State University, Russia, Barnaul, e-mail: igor_dubina@yahoo.com

\section{DOES DEMOCRACY BOOST INNOVATION?}

\section{A review on Campbell, David F. J. (2019) «Global Quality of Democracy} as Innovation Enabler. Measuring Democracy for Success». New York, NY: Palgrave Macmillan

\author{
И.Н. Аубина
}

Новосібір ұлттық зерттеу мемлекеттік университеті, Ресей, Новосібір қ. А^тай мемлекеттік университеті, Ресей, Барнаул к., е-mail: igor_dubina@yahoo.com

\section{Аемократия инновацияны қолдай ма?}

Монографияға шолу: Кэмпбем^ А.Ф.Аж. Аемократияның интегралдық сипаты инновацияның катализаторы ретінде. Тұрақты даму үшін демократияны бағалау. Нью-Йорк: Palgrave Macmillan, 2019 жыл.

\section{И.Н. Аубина}

Новосибирский национальный исследовательский Государственный университет, Россия, г. Новосибирск А^тайский государственный университет, Россия, г. Барнаул, e-mail: igor_dubina@yahoo.com

\section{Способствует ми демократия инновациям?}

Обзор монографии Кэмпбемла А.Ф.Аж. «Интегральное качество демократии как катализатор инноваций. Измерение демократии А^я устойчивого развития». Нью Йорк: Palgrave Macmillan, 2019

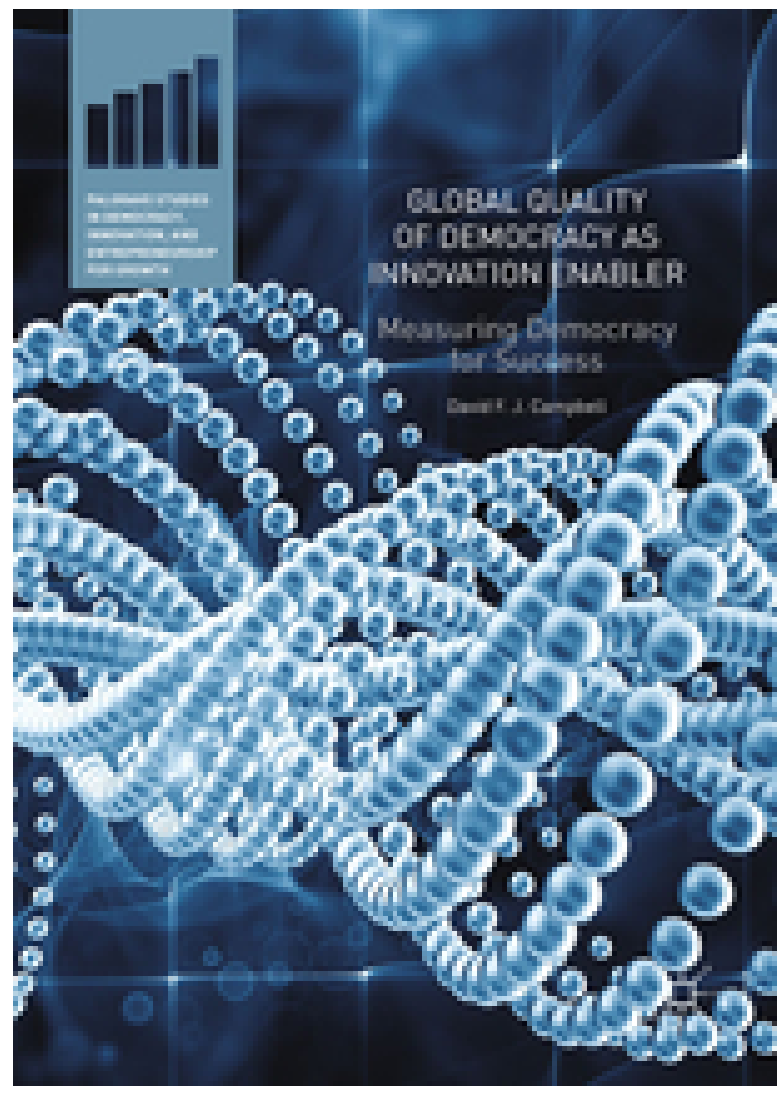

In 2019, Palgrave Macmillan released a new monograph by David F. J. Campbell, an AustrianAmerican researcher and Privat-Dozent with the University of Vienna, the University of Applied Arts Vienna, and Danube University Krems, titled as Global Quality of Democracy as Innovation Enabler. The book was published in the frame of the Palgrave book series on Studies in Democracy, Innovation, and Entrepreneurship for Growth (https://link.springer.com/book/10.1007/9783-319-72529-1, https://www.palgrave.com/de/ book/9783319725284).

This book addresses and analyses the interrelation and interdependence of democracy and economic development, based on innovation. The book refers to such domains as democracy, the quality of democracy, knowledge, sustainable development and innovation. Based on a number of theoretical conceptions as well as extensive empirical analysis, Dr. Campbell argues and substantiates the key idea of the book on democracy as innovation enabler.

One of key elements of the conceptual and contextual framework of the book is an extended understanding of the Innovation Triple Helix of 
university-industry-government relationships (Etzkowitz and Leydesdorff, 1995). The Triple Helix represents a basic core model of innovation for the "knowledge economy". The concept of the Triple Helix has been further developed toward the Quadruple Helix (Carayannis and Campbell, 2009) by adding "civil society" (citizens) as the fourth helix. The Quadruple Helix as an extension of the Triple Helix describes the "knowledge society" and "knowledge democracy" (Carayannis and Campbell, 2012). In that sense, the Quadruple Helix is emphasizing the perspective of democracy as being an import perspective for knowledge and innovation, and in that sense the "Quadruple Helix innovation system" can also serve as a concept, model and theory for the proposition (hypothesis) of "democracy as an innovation enabler".

The author extends the canonical conception of democracy and formulates the main research hypothesis and propositions of his work as follows:

1) Democracy as political pluralism and diversity encourages also a diversity of knowledge and innovation (Carayannis and Campbell, 2009), which is necessary for development (also economic development and economic growth).

2) Advanced economies and, at least in principle, emerging and developing economies are driven by knowledge and innovation, so they require a democracy also.

3) The economic successes of non-democracies or autocracies (authoritarian and semi-authoritarian regimes) are being overestimated anyway, because autocracies are also benefitting from the knowledge production and innovation systems of democracies and semi-democracies, so in that sense autocracy is depending on democracy and the knowledge and innovation of democracy in the global system.

4) Political pluralism, and a heterogeneity and diversity of different knowledge and innovation modes, should mutually support and reinforce each other, so there is a co-evolution of democracy, of "democracy of knowledge" and of "democracy as innovation enabler".

Testing these hypotheses requires answering the following research questions of the analysis: How to conceptualize and to measure democracy and the quality of democracy in global comparison? Dr. Campbell notes that without a measurement it is difficult to envision how concepts and theories of democracy can be developed further.

In order to answer this question, the author suggests a corresponding model that identifies the following five basic dimensions of democracy: freedom, equality, control, sustainable development, and self-organization (political self-organization). This five-dimensional model partially relates to HansJoachim Lauth's three-dimensional approach, where Lauth introduced the following three dimensions: freedom, equality and control (Lauth, 2016; Lauth and Schlenkrich, 2018). A key and crucial argument for Campbell's model is that a quality-of-democracy understanding based on sustainable development relates crucially with economic growth, but more so with economic development. Moreover, the meaning of classical terms of democracy, such as freedom and equality, are also considered in the context of sustainable development. The conceptualisation of democracy is also set in reference to innovation.

The author collected a huge set of statistical data for this analysis according to the suggested model of a quintuple-dimensional structure of democracy and quality of democracy. The collected dataset focuses on 161 countries (territories) and covers a fifteenyear period of 2002-2016. All data are publicly available. Advanced and emerging countries are being equally covered. This large-scale comparison includes not only OECD countries, but also nonOECD countries, for example Brazil, Russia, China and India. By this, the model addresses more than ninety-nine percent of the world population. The model refers not only to democracies, but also to semi-democracies and non-democracies. In that sense the book is unique, because there is no comparable publication out there, addressing these issues in a world-wide perspective.

The analysis of collected data proves (at least, partially) the formulated research hypothesis and propositions. Thus, in case of the OECD or the advanced economies, freer countries are also likelier to develop higher levels of sustainable development. Implications of this may be that the achievement of advanced levels of sustainable development (beyond a certain threshold) is not possible without achieving progress (perhaps also beyond a certain threshold) in the dimension of freedom: in that sense the quality of democracy clearly acts as an "innovation enabler" (at the higher levels of development); and paths of development of the OECD or the advanced economies are more similar to each other than in context of the non-OECD countries and their trajectories of development.

From the research on the non-OECD countries, a special focus has been placed on Russia with the tendency of a reduced political freedom, China as a non-democracy but rapidly developing economy, Hong Kong and India. Generally, the cases of these economies are not easily set into the main conceptual framework of the book. 
In context of the comparative discussion of India and China, the question and possible proposition was introduced, whether political freedom becomes more important when non-political sustainable development progresses to higher levels (beyond a certain threshold). Then there may be more effects of "democracy as an innovation enabler". Implications of such scenarios further are that non-political sustainable development is possible to certain levels without political freedom, but beyond such threshold levels, further non-political sustainable development may be exposed to phenomena of a bottle-necking or ceiling, should this not be paralleled and supported by a sufficient maturing of political freedom (Campbell, 2019: 194).

Dr. Campbell concludes that the Chinese path is not that clear with regard to inner and domestic politics, because "a good democracy would require that political developments are set in good balance with developments in society and the economy" (Campbell 2019: 25). So, it is questionable in the long run, whether can China continue its pace of economic and social (societal) development, without allowing and introducing more political freedom, without finally turning, developing and transforming more into a democracy. For example, authoritarian or totalitarian regimes can learn and can try to implement innovations that were explored and developed by democracies, without establishing a democracy, by this attempting to bypass democracy and political freedom. So, according to the author, it is difficult to perceive how China wants to continue its impressive track record of current economic development, without allowing and introducing more political freedom, and a process of democracy establishment and democratization as a final consequence and in final consequence of this ultimo ratio.

In the case of Hong Kong, a region politically embedded within China, there is a positive correlation and association between a high developmental status and advanced political freedom. So China may intentionally allow this political freedom to (and in) Hong Kong, so that China can participate in and profit from the advances of Hong Kong in knowledge (knowledge production) and innovation (knowledge application) (Campbell, 2019).

The case of Russia does not support the main conception of the book as well. The author notes that the level of non-political sustainable development of Russia increased during the years 2002-2013 and decreased since 2014, however, the degree of political freedom actually declined during the same period of time. Therefore, in the case of Russia, there was actually a negative trade-off cycle between non-political sustainable development and political freedom in the 2000s and 2010s, with the following interaction: more non-political sustainable development on the one hand, but less political freedom on the other. There is more political freedom in Russia than in China, in relative terms (during the time window of 20022016). However, in absolute terms, Russia does not represent a free country. While Freedom House categorized Russia as "partly free" for the period 1991-2003, Freedom House changed the rating of Russia to a "not free" country since 2004. This has the consequence that "not free" Russia outperforms the "freer" Latin America in important areas and on the basis of specific indicators of and for nonpolitical sustainable development (Campbell, 2019: 193).

Nevertheless, the author generally concludes that within context and the limitations of the model used in his research, knowledge and innovation act as drivers for development and progress not only for the OECD, but also the non-OECD countries. In that sense, the concepts of knowledge economy and knowledge society (furthermore knowledge democracy) apply to advanced economies and societies as well as to emerging and developing economies and their associated societies.

The higher the economic and social level of a country has developed and progressed, the higher is the probability of a stronger link and mutual reinforcement of political freedom and nonpolitical sustainable development, which indicates a co-evolution of democracy and of economic and social (societal) development. This would imply that "democracy as an innovation enabler" may be more the case, when society and economy have advanced beyond a certain threshold of development.

Advanced economies appreciate higher levels of political freedom. Therefore, this supports beliefs or assumptions of a coevolution of the economy and of democracy in the high end of performance (of sustainable development). The freedom lead to the advantage of the OECD is also stronger (superior) for political freedom than for economic freedom, meaning that OECD countries are more leading with regard to political freedom, and are less leading with regard to economic freedom, when compared with the non-OECD countries. This coevolution of freedom (political freedom), economy and sustainable development for the advanced economies also clearly supports (at least for this country group) the proposition of "democracy as an 
innovation enabler," because advanced economies depend on knowledge and innovation as crucial drivers (Campbell, 2019: 216).

The general conclusion is that "the diversity (not only political diversity and political pluralism, but also knowledge and innovation diversity) within democracies may feed effectively into the next-generation creations of knowledge production and innovation system evolution, which will be necessary for progress and further advances of knowledge society, knowledge economy, and knowledge democracy in a global format" (Campbell, 2019: 339). Thus, knowledge economy, knowledge society and knowledge democracy align and associate together in coevolution.

\section{References}

Campbell D.F.J. (2019) Global Quality of Democracy as Innovation Enabler. Measuring Democracy for Success. New York, NY: Palgrave Macmillan.

Carayannis E., Campbell D. (2009) "Mode 3" and "Quadruple Helix": toward a 21st century fractal innovation ecosystem. International Journal of Technology Management, vol. 46(3-4), pp. 201-234.

Carayannis E.G., Barth T.D., Campbell D.F.J. (2012) The Quintuple Helix innovation model: global warming as a challenge and driver for innovation. Journal of Innovation and Entrepreneurship, vol. 1(2), pp. 1-12.

Etzkowitz H., Leydesdorff L. (1995) The Triple Helix: University - Industry - Government relations a laboratory for knowledge based economic development. EASST Review, vol. 14(1), pp. 14-19.

Lauth H.-J. (2016) The internal relationships of the dimensions of democracy: the relevance of trade-offs for measuring the quality of democracy. International Political Science Review, vol. 37(5), pp. 606-617, http://journals.sagepub.com/doi/ full/10.1177/0192512116667630.

Lauth H.-J., Schlenkrich O. (2018) Making trade-offs visible: theoretical and methodological considerations about the relationship between dimensions and institutions of democracy and empirical findings. Politics and Governance, vol. 6(1), pp. 78-91, https:// www.cogitatiopress.com/politicsandgovernance/article/view/1200. 